\title{
Sosiaalipedagoginen työote sosiaalityössä - brittiläinen näkökulma
}

Charfe, Lowis \& Gardner, Ali

Social Pedagogy and Social Work

Sage, London 2019

\section{Elina Nivala}

owis Charfen ja Ali Gardnerin teos Social Pedagogy and Social Work asettuu jatkoksi aiemmille brittien tai brittitaustaisten kirjoittajien englanninkielisille sosiaalipedagogiikan oppikirjoille (Hatton 2013; Stephens 2013). Kirja on kirjoitettu lähtien liikkeelle kirjoittajien oman kotimaan tilanteesta ja tarpeista ja etsien sovellus- ja peilauspintoja nimenomaan sieltä, vaikka toki - ja onneksi - kirjassa etsitään kiinnittymiskohtia alan historiallisiin juuriin ja keskusteluun myös muissa maissa. Suomalaiselle sosiaalipedagogiikan tuntijalle kirja on kiinnostavaa luettavaa ainakin siitä näkökulmasta, miten brittiläinen keskustelu sosiaalipedagogiikasta kehittyy ja miten siellä jäsennetään sosiaalipedagogista ymmärrystä maailmasta, tässä tapauksessa erityisesti sosiaalityöstä. Suomalaiselle lukijalle en kuitenkaan suosittelisi teosta johdatukseksi sosiaalipedagogiikkaan, sillä kirjan kautta muodostuva kuva kohteestaan on varsin kapea ja yksioikoinen. Sen sijaan uskon ymmärtäväni, miksi tällainen kirja on koettu tarpeelliseksi Britanniassa ja brittiläisen sosiaalipedagogisen työn kehittämisessä.

Teos Social Pedagogy and Social Work muodostuu johdanto- ja johtopäätösluvun lisäksi kuudesta luvusta, jotka ovat jommankumman kirjoittajan kirjoittamia. Lowis Charfe on University of Central Lancashiren yliopistonlehtori, joka vastaa yliopistossaan sosiaalipedagogiikan kandidaattitutkinnon koulutuksesta ja on sosiaalipedagogisen johtajuuden maiste- 
ritutkinnon toinen johtaja. Hän on kirjoittanut kolme lukua, joista luku 1 määrittelee sosiaalipedagogiikkaa ja sen yhteyttä sosiaalityöhön, luku 2 esittelee sosiaalipedagogiikan avainajattelijoita ja luku 4 kuvailee sosiaalipedagogisen työn kehittämistä Isossa-Britanniassa lasten, nuorten ja perheiden parissa. Ali Gardner on samoin University of Central Lancashiren yliopistonlehtori ja toimii sosiaalipedagogisen johtajuuden maisteritutkinnon toisena johtajana. Hän on kirjoittanut luvun 3, joka avaa sosiaalipedagogiikan keskeisiä käsitteitä, luvun 5, joka tarkastelee sosiaalipedagogisen työotteen toteuttamista aikuissosiaalityössä, sekä luvun 7, jossa käsitellään riskiarviointia sosiaalipedagogisen työn erityiskysymyksenä. Näiden lukujen lisäksi kirjassa on Lindy Simpsonin kirjoittama luku 6, jossa tämä lasten ja nuorten osallistumisen edistämisen kysymyksiin erikoistunut sosiaalityön konsultti ja luennoitsija käsittelee osallistumista sosiaalipedagogisen työn ja sosiaalityön periaatteena, muotona ja tavoitteena.

\section{Sosiaalipedagogiikan ajattelijat}

Kirjan toisessa luvussa esitellään lyhyesti joukko sosiaalipedagogisia ajattelijoita, tai ehkä pikemminkin ajattelijoita, jotka kirjan kirjoittajat määrittelevät sosiaalipedagogisiksi. Osa esitellyistä on itse itsensä sosiaalipedagogiikan historiaan kirjoittaneita, kuten Paul Natorp (1854-1924) ja Herman Nohl (1879-1960), jotka kehittivät sosiaalipedagogiikkaa tieteenalana Saksassa 1800-luvun lopulla ja 1900-luvun alkupuoliskolla kiinnittämällä ajatuksensa sosiaalipedagogiikan käsitteeseen. Osa on niin sanotusti sosiaalipedagogisoituja ajattelijoita, joiden ajatuksia ja toimintaa on kirjoitettu osaksi sosiaalipedagogiikan teoreettista keskustelua tulkitsemalla niitä sosiaalipedagogisesta viitekehyksestä ja rakentamalla heidän ajatuksiaan siten osaksi sosiaalipedagogiikan teorioita. Tällaisia ovat esimerkiksi sveitsiläinen Johann Heinrich Pestalozzi (1746-1827), jota pidetään kokonaisvaltaisen pikkulapsipedagogiikan ja lastentarhainstituution isänä, sekä brasilialainen vapautuksen pedagogiikan luoja Paulo Freire (1921-1997).

Tällaisten yleisemminkin sosiaalipedagogisiksi ajattelijoiksi nähtyjen henkilöiden lisäksi kirjassa esitellään muutamia ajattelijoita, joiden ajattelussa on sosiaalipedagogisesti kiinnostavia elementtejä ja joiden teoreettisia ideoita on joissain yhteyksissä hyödynnetty sosiaalipedagogisessa tutkimuksessa tai käytännön työn kehittämisessä. Heidän määrittelemisensä sosiaalipedagogiikan avainajattelijoiksi, kuten kyseisen luvun otsikossa tehdään, on kuitenkin jossain määrin kyseenalaista. Esimerkiksi italialai- 
nen Maria Montessori (1870-1952) ja (valko)venäläinen psykologi Lev Vygotsky (1896-1934) ovat ehdottomasti kiinnostavia ja omalla alallaan ansioituneita teoreetikoita. Heidän teoreettisessa perinnössään on sosiaalipedagogisessakin työssä sovellettavia elementtejä, mutta heidän määrittelemisensä sosiaalipedagogiikan avainajattelijoiksi kertoo enemmän brittiläisen sosiaalipedagogisen keskustelun luonteesta (ks. myös Hatton 2013, 24-25) kuin sosiaalipedagogiikan teoriaperustasta. Esimerkiksi Vygotskyn ajattelusta on poimittu hänen teoriansa lähikehityksen vyöhykkeestä (Zone of Proximal Development), joka esitellään yksinkertaistettuna oppimisen tukemisen ideana. Sellaisena se voi auttaa käytännön työssä ymmärtämään ja tukemaan ihmisten oppimista erilaisissa sosiaalisissa tilanteissa, mutta kyse on nimenomaan oppimisen (learning) tukemisesta, mikä ei ole erityisen keskeinen tarkastelun kohde sosiaalipedagogiikassa yleisemmin. Englanninkielestä puuttuu sanasto sellaiselle kasvun tukemiselle ja kasvatustyölle, jota sosiaalipedagogiikassa selvästi enemmän tarkastellaan. Ehkä tästä syystä brittikirjallisuudessa näyttää korostuvan oppimisen näkökulma ja siten myös oppimisen teoretisoinnit. Tähän liittyen myös käsite Learning Zone on kirjassa nostettu keskeiseksi sosiaalipedagogiikan käsitteeksi.

Toinen seikka, josta muutamien ei varsinaisesti sosiaalipedagogisten ajattelijoiden nimeäminen sosiaalipedagogiikan avainajattelijoiksi kertoo, on brittiläisen sosiaalipedagogiikan kehitykseen vaikuttava laajempi kieliongelma: Koska sosiaalipedagogiikan historiallinen kehittyminen ja aivan viime vuosiin asti myös uudempi keskustelu on tapahtunut muilla kielillä kuin englanniksi, on monien brittien vaikeaa tavoittaa niin sanottujen varsinaisten sosiaalipedagogiikan teoreetikoiden ajatuksia ja hyödyntää heidän tekstejään, koska niitä ei ole juurikaan käännetty englanniksi tai käsitelty englanninkielisessä kirjallisuudessa. Niinpä helpommaksi tulee tulkita sellaisten lähitieteenaloja edustavien teoreetikoiden ajattelua sosiaalipedagogiseksi, joiden tuotantoa on julkaistu tai joiden teorioita on käsitelty paljon englannin kielellä. Se tarjoaa mahdollisuuden muodostaa ulospäin teoreettisesti vakuuttavaa pohjaa brittiläisille sosiaalipedagogiikan tulkinnoille, vaikka nämä teoreettiset tukipuut eivät kiinnittyisikään sosiaalipedagogiikan tieteenalan omaan teoriaperustaan vaan lähitieteenaloihin, kuten kasvatustieteeseen (Montessori) tai psykologiaan (Vygotsky). Sosiaalipedagogiikan tieteenalan kehittymisen kannalta tämä on kuitenkin jossain määrin ongelmallista. Toki tällaista eri teoreetikoiden sosiaalipedagogisoimista tehdään jatkuvasti myös muualla (ks. esim. 
Nivala \& Ryynänen 2019) ja sitä on perusteltuakin tehdä, sillä monien lähitieteenalojen teoreettisessa keskustelussa ja tutkimuksissa on paljon sellaisia näkökulmia, jotka auttavat ymmärtämään sosiaalipedagogiikan tarkastelemia ilmiöitä. Se tulisi kuitenkin tehdä perustellusti ja etsien uusien teoreetikoiden ajattelulle kiinnittymiskohtia sosiaalipedagogiikan omasta teoriaperinteestä. Esimerkiksi psykologian teoreetikoiden kyseenalaistamaton esitteleminen sosiaalipedagogiikan avainajattelijoina hämärtää sosiaalipedagogiikan omaa tieteenalaluonnetta. Vaarana on, että sosiaalipedagogiikka alkaa näyttää vain kokoelmalta lähialojen sopivia teorioita ilman omaa teoreettista perustaa, vaikka alalla on pitkä oman teoreettisen keskustelun perinne.

\section{Sosiaalipedagogiikan käsitteet}

Kirjan luku Social Pedagogy Concepts esittelee kirjoittajien mukaan sosiaalipedagogiikan avainteorioita ja -käsitteitä, jotka on valittu sillä perusteella, että ne tarjoavat hyvän perustan sosiaalipedagogiselle käytännölle. Itse asiassa luku muodostuu nimenomaan käytäntöä palvelevista termeistä, joita käytetään yleisemminkin brittiläisessä sosiaalipedagogisessa keskustelussa kuvaamaan sosiaalipedagogista työtapaa ja työskentelyperiaatteita (vrt. ThemPra 2019). Teorioiden ja käsitteiden sijaan luvussa esitellään siis pikemminkin sosiaalipedagogisen työn periaatteita, työotteen elementtejä ja tapoja mallintaa työtä. Näillä on toki teoreettiset ja käsitteelliset juurensa, mutta niihin ei luvussa juurikaan perehdytä. Liikkeelle lähdetään termistä Haltung, joka kuvastaa juuri tietynlaista ajattelu- ja toimintatapaa tai työnteon eetosta. Muita luvussa käsiteltyjä termejä ja ilmauksia ovat Head, heart and hands eli pää, sydän ja kädet, luovuus, kolme P:tä (the three Ps), Common third eli yhteinen kolmas, reflektio, Learning zone eli oppimisvyöhyke, lähikehityksen vyöhyke, Relational universe eli relationaalinen tai suhteista muodostuva maailma sekä timanttimalli (The Diamond model) (vrt. sosiaalipedagogisen työotteen jäsennys Nivala \& Ryynänen 2019, 185-233).

Oikeastaan kaikki luvussa tarkastellut käsitteet kuvaavat korostuneesti sitä, miten sosiaalipedagogista työtä tehdään tai tulisi tehdä. Ne eivät kuitenkaan avaa teoreettista ymmärrystä siitä, miksi työtä tehdään, siis mitä sosiaalipedagogisessa työssä tavoitellaan. Tällaisia sosiaalipedagogisen työn tavoitetta teoreettisesti avaavia käsitteitä voisivat olla esimerkiksi sellaiset sosiaalipedagogisessa keskustelussa yleiset termit kuin integraatio, 
emansipaatio, toimijuus ja marginalisaatio. Kaikki nämä ovat käsitteitä, jotka voidaan määritellä eri tavoin ja siltä pohjalta ymmärtää työn tavoitteita eri tavoin. Se, että osa näistä tavoitekäsitteistä kyllä esiintyy kirjassa ikään kuin itsestään selvinä mainintoina, kertoo brittiläisen keskustelun kiinnittymisestä sosiaalipedagogiseen keskusteluperinteeseen mutta samalla se kertoo vielä teoreettisesti varsin pinnallisesta sosiaalipedagogiikan ymmärryksestä. Kun nämä tavoitekäsitteet otetaan itsestäänselvyyksinä, oletetaan, että on olemassa jokin yksi yhtenäinen käsitys sosiaalipedagogiikasta, jossa jaetaan samoin määritellyt tavoitteet ja käsitteet. Tällöin ei huomioida tieteenalan erilaisia suuntauksia, joiden piirissä esimerkiksi integraatio voidaan määritellä toisaalla yksilöiden sopeuttamisena yhteiskunnan vallitsevaan järjestykseen ja toisaalla emansipaation kanssa yhteen kietoutuvana jokaisen yhteiskunnan jäsenen itsetoteutuksen edistämiseen ja rakenteiden muuttamiseen tähtäävänä prosessina (ks. esim. Nivala \& Ryynänen 2019, 152-158). Tällaisten tavoitekäsitteiden tarkastelu ja määrittely on oleellista sosiaalipedagogiikan tieteenalan ja sen itseymmärryksen kehittymisessä, mutta sitä Charfen ja Gardnerin teos ei edistä. Se keskittyy termeihin, joiden pohjalta voidaan kehittää sosiaalipedagogisen käytännön työn muotoja, mutta samalla se jättää tukematta tämän työn tekijöiden tietoisuutta työn tavoitteiden määrittelyyn liittyvistä ja tieteenalan ymmärtämisen kannalta oleellisista teoreettisista kysymyksistä.

\section{Sosiaalipedagoginen sosiaalityö}

Kirjan kiinnostavinta antia suomalaisen lukijan kannalta on mielestäni luku 4, jossa kuvataan sosiaalipedagogisen työotteen kehittämistä Isossa-Britanniassa, erityisesti sosiaalityössä lasten, nuorten ja perheiden parissa. Luvussa tuodaan esiin kehittämistyön yhteiskunnallista ja poliittista taustaa sekä niitä lastensuojelutyön tarpeita, joihin sosiaalipedagogisesta ajattelusta ja toiminnasta ryhdyttiin etsimään vastauksia. Lisäksi avataan sitä määrätietoisen kehittämistyön prosessia, jonka tulosta brittiläisen sosiaalipedagogiikan rakentuminen on, ja kerrotaan muutamien esimerkkien kautta, millaisia sosiaalipedagogisia työmuotoja on jo vakiintunut ja millaisia uusia mahdollisuuksia on avautumassa.

Myös luku 5 on kiinnostava hahmotellessaan sosiaalipedagogisen työotteen soveltamismahdollisuuksia sosiaalityössä aikuisten parissa. Sen lähestymistapa aiheeseen vain on hyvin erilainen kuin edellisen luvun, sil- 
lä se ei juurikaan kerro siitä, millaista konkreettista kehittämistyötä on tehty, vaan se käy läpi käsiteluvussa kuvattujen termien soveltamista aikuisten parissa tehtävässä työssä. Luvussa avataan esimerkiksi sitä, miten timanttimallin avulla voidaan painottaa sellaisia sosiaalityön käytäntöjä, jotka ovat vahvuusperustaisia ongelmaperustaisuuden sijaan, pyrkivät edistämään hyvinvointia ja onnellisuutta, perustuvat henkilökohtaisiin lämpimiin suhteisiin ja positiivisten kokemusten vahvistamiseen sekä tukevat kokonaisvaltaista oppimista ja voimaantumista. Kyse on oikeastaan käsiteluvun termien tarkentamisesta ja sovellusmahdollisuuksien konkretisoimisesta, mutta luku tarjoaa myös joitakin uusia näkökulmia siihen, mitä käytännössä sosiaalityössä - tai laajemmin sosiaalialan työssä - voidaan ajatella ja tehdä toisin kuin on totuttu. Luvun lopussa esitetään muutama varoituksen sana siitä, miten sosiaalipedagogiikan termistöä voidaan hyödyntää myös ulkokohtaisesti esimerkiksi lainsäädännössä perustelemaan asioita, jotka todellisuudessa heikentävät ihmisten hyvinvoinnin mahdollisuuksia (vrt. Nivala \& Ryynänen 2019, 202-203). Tämä on tärkeä kriittinen havainto.

Osallistumisen kysymyksiin keskittyvä luku 6 tuo esiin näkökulmia, jotka Suomessa ovat tuttuja osallisuuden käsitteeseen liittyvästä keskustelusta, erityisesti lapsen oikeuksiin ja lasten ja nuorten osallistumisen edistämiseen liittyen. Osallistumista käsitellään erityisesti toimintaan osallistujien mahdollisuuksina tulla kuulluksi, vaikuttaa ja saada aikaan muutoksia omassa ympäristössään sekä asiakkaiden oikeutena osallistua päätöksiin, jotka liittyvät heidän elämäänsä. Tämä osallistumisen idea liitetään luvussa sosiaalipedagogiseen tapaan tehdä sosiaalityötä, jossa korostuu esimerkiksi kokonaisvaltainen kohtaaminen, ihmisten - asiakkaiden - elämismaailman ymmärtäminen ja vallan elementtien tunnistaminen ja vallan jakaminen vuorovaikutussuhteessa. Meille selvästi vieraampi näkökulma sen sijaan on luvussa 7 käsitelty suhtautuminen riskiarviointien tekemiseen. Varsinkin lastensuojelun kentällä riskikeskeisyys näyttää olevan brittiläisessä keskustelussa hyvin perustavanlaatuinen toiminnan ominaispiirre, jota vastustamaan sosiaalipedagoginen työote nousee tarjoamalla sekä perusteluja että työvälineitä toisin toimimiselle.

\section{Lopuksi}

Vielä kymmenen vuotta sitten ei juuri ollut olemassa englanninkielisiä julkaisuja sosiaalipedagogiikasta, sillä britit olivat vasta löytämässä alan, ja käytännössä vasta heidän kiinnostuksensa kautta englannin kielestä al- 
koi kehittyä sosiaalipedagogisen keskustelun kieli. Sitä ennen alan keskustelua oli käyty lähinnä kielialuekohtaisesti eli saksankielisellä alueella omaa keskusteluaan, espanjan- ja portugalinkielisellä omaa iberoamerikkalaista keskustelua, Pohjoismaissa omaansa skandinaavisilla kielillä ja ilmeisesti Itä-Euroopan maissa jonkinlaista omaa slaavilaista keskustelua. Koska angloamerikkalaisessa tiedemaailmassa ei tunnettu sosiaalipedagogiikan käsitettä ja siihen kiinnittyvää keskusteluperinnettä, ei englanti ollut sosiaalipedagogiikan kieli eikä alalla siis ollut laajasti käytössä olevaa maailmankieltä. Näin ollen ei ollut olemassa maailmanlaajuista keskusteluakaan.

Kymmenessä vuodessa tilanne on muuttunut radikaalisti: Britit ovat löytäneet sosiaalipedagogiikan ja ryhtyneet määrätietoisesti kehittämään omaa brittiläistä sovellustaan sekä tekemään tutkimusta ja julkaisemaan sitä. Samalla on muuttunut relevantiksi myös muille julkaista tutkimusartikkeleita englanniksi. Lisäksi sosiaalipedagogiikka näkyy ja alan tutkijat esiintyvät englanninkielisissä tieteellisissä konferensseissa huomattavasti aiempaa enemmän - ja nyt on olemassa myös omia sosiaalipedagogisia englanninkielisiä tieteellisiä konferensseja. Tieteellisiä tekstejä, erityisesti artikkeleita, julkaistaankin jo englanniksi varsin paljon. Jonkin verran ilmestyy myös erilaisia artikkelikokoelmia. Alan oppikirjoja on englanniksi ilmestynyt kuitenkin vain muutamia, ja ne ovat pääosin brittien kirjoittamia (Hatton 2013; Stephens 2013). Tämä on sikäli epäsuotuisa tilanne, että sosiaalipedagogiikkaan englannin kielellä tutustuva kohtaa helposti vain brittiläisen näkökulman värittämän kuvan sosiaalipedagogiikasta eikä juuri muuta, minkä pohjalta muodostaa kokonaiskuvaa alasta. Ja brittiläinen näkökulma on toistaiseksi varsin kapea.

Brittiläistä sosiaalipedagogiikkaa on kehitetty vahvasti käytännön työn tarpeista lähtien ja käytännön työtä varten. Tämä näkyy - luonnollisesti siinä, miten sosiaalipedagogiikka siellä ymmärretään ja miten siitä kirjoitetaan. Charfen ja Gardnerin teoksessa sosiaalipedagogiikka piirtyy esiin tietynlaisena tapana tehdä sosiaalityötä tai laajemmin sosiaalialan (tai sosiaalista) työtä (vrt. Nivala \& Ryynänen 2019, 265-267). Kirja ei mielestäni onnistu kehittämään lukijassa ymmärrystä, että sosiaalipedagogiikka on tietynlaisen käytännön työn lisäksi tieteenala, johon käytännön työn perustelut ja periaatteet juurtuvat ja jolla on omat teoreettiset juurensa ei vain lähialojen teorioita juurinaan - sekä monimuotoinen teoreettinen nykykeskustelu. Koska kyse on tieteenalasta, on aivan selvää, että ei ole olemassa vain yhtä sosiaalipedagogiikan tulkintaa, vain yhtä käsitystä so- 
siaalipedagogisen työn tarkoituksesta ja yksiselitteisiä määritelmiä eri käsitteille. Tieteenala muodostuu monenlaisista teorioista, jotka kiinnittyvät erilaisiin, toisistaan poikkeaviin ja ristiriitaisiinkin tulkintoihin todellisuudesta, tiedosta, tieteestä, käytännön työstä ja sen tarkoituksista ja niin edelleen. Tällaista ymmärrystä kirja ei edistä vaan kuvaa varsin yksiselitteisen vaikkakin monenlaisissa ympäristöissä ja erilaisten ihmisten parissa toteutettavissa olevan sosiaalipedagogisen työtavan. Vaikka sitä ei kirjassa ehkä tarkoitetakaan, tarjoaa se kokonaisuutena varsin vahvan mielikuvan, että sosiaalipedagogiikka on yhtä kuin sosiaalipedagoginen työote.

Social pedagogy, therefore, as a philosophical, ethical and critical reflective way of working, supports us in placing the relationship right back at the heart of social work practice. (s. 8, kursiivi EN)

Sosiaalipedagogiikkaa tarjotaan sosiaalityöntekijöille ja muille sosiaalisen työn tekijöille uudenlaisena ja samalla tuttuna tapana tehdä työtä haavoittuvissa asemissa ja tilanteissa elävien ihmisten kanssa asettumalla suhteeseen ja vuorovaikutukseen heidän kanssaan. Sen kuvataan palauttavan mielekkyyden ja tarkoituksen tunteen työhön, josta hallinnollinen, prosessiorientoitunut, riskitietoinen ja kontrolliin pyrkivä työote on tehnyt työntekijöiden arvojen ja sitoumusten vastaista. Tällaisen viestin tuojana kirja on varmasti tarpeellinen ja toimiva brittiläisessä sosiaalityön toimintaympäristössä. Se palvelee sekä sosiaalipedagogisten sosiaalityön käytäntöjen kehittäjiä että työhönsä uutta sisältöä ja mieltä etsiviä sosiaalityöntekijöitä. Mutta onko sillä annettavaa muille? Antaisinko kirjan esimerkiksi suomalaiselle sosiaalityöntekijälle?

Mielestäni kirja voisi toimia oppimateriaalina esimerkiksi sosionomikoulutuksessa tarjoamassa näkökulmia yhteiseen pohdintaan: näin sosiaalipedagogista työotetta toteutetaan sosiaalityössä Isossa-Britanniassa - mitähän se voisi olla meillä? Se ei kuitenkaan toimi ainoana lähteenä sosiaalipedagogiikan tai edes sosiaalipedagogisen työotteen ymmärtämisen pohjaksi. Kirjan nimen ei pidä antaa hämätä, eli ei pidä ajatella, että kirja toimisi sosiaalipedagogiikasta kiinnostuneelle sosiaalityöntekijälle johdatuksena sosiaalipedagogiseen ajatteluun tai että se jäsentäisi perusteellisesti sosiaalipedagogiikan ja sosiaalityön suhdetta. En usko, että se myöskään vakuuttaa sosiaalipedagogiikkaan mahdollisesti epäilevästi suhtautuvaa sosiaalityön asiantuntijaa siitä, että sosiaalipedagogiikka on sosiaalityön kannalta relevantti ja kiinnostava tieteenala, joka voi tarjo- 
ta näkökulmia sosiaalityössä kohdattavien ilmiöiden ymmärtämiseen ja työn kehittämiseen teoreettisesti tukevalta pohjalta. Siihen kirjan tarjoama kuva sosiaalipedagogiikasta on liian heppoinen - sosiaalipedagogiikka piirtyy tietynlaisena arvoperustaisena ja varsin idealistisena työotteena, jota voi yrittää toteuttaa myös sosiaalityön kentällä mutta jonka kaltaiseen toimintatapaan lukija voi kokea löytävänsä vankempaa teoreettista pohjaa esimerkiksi positiivisesta psykologiasta. Tällaista virheellistä mielikuvaa en halua olla sosiaalipedagogiikasta levittämässä, joten en antaisi kirjaa suomalaiselle sosiaalityöntekijälle, jollen tietäisi hänen tuntevan sosiaalipedagogiikkaa jo ennestään nimenomaan tieteenalana. Jo valmiiksi sosiaalipedagogisesti orientoituneelle sosiaalityöntekijälle tai sosiaalisen työn toimijalle sen sijaan voisin suositella kirjaa käytännön vinkkikirjana, josta voi saada ideoita omaan työhön ja sen sosiaalipedagogiseen kehittämiseen.

\section{LÄHTEET}

Hatton, K. 2013. Social pedagogy in the UK. Theory and practice. Dorset: Russel House Publishing.

Nivala, E. \& Ryynänen, S. 2019. Sosiaalipedagogiikka. Kohti inhimillisempää yhteiskuntaa. Helsinki: Gaudeamus.

Stephens, P. 2013. Social Pedagogy: Heart and Head. Bremen: EHV.

ThemPra 2019. Key concepts in Social Pedagogy. Saatavissa http://www.thempra.org. uk/social-pedagogy/key-concepts-in-social-pedagogy/ (haettu 11.12.2019). 
152

- Sosiaalipedagoginen aikakauskirja, vuosikirja 2019, vol. 20 